\title{
Religio-centric fashion advantage on marketing performance: The role of innovativeness and customer responsiveness
}

\author{
La ventaja de la moda religiocentrica en el rendimiento de la \\ comercialización: el papel de la innovación y la responsabilidad del cliente
}

\author{
Hendar Hendar ${ }^{1 *}$, Tatiek Nurhayati ${ }^{1}$, Gita Sugiyarti ${ }^{2}$ \\ ${ }^{1}$ Universitas Islam Sultan Agung (UNISSULA), Indonesia \\ ${ }^{2}$ Universitas 17 Agustus 1945 Semarang, Indonesia
}

Received 16 January 2017; accepted 03 April 2018

Available online 27 September 2018

\begin{abstract}
This study aims to investigate and examine the role of religio-centric fashion advantage in mediating the relationship of innovativeness and customers responsiveness with marketing performance in religious-based fashion industry. Structural equation modeling is used to test the research hypotheses on data basis of Islamic small fashion business in Indonesia. The data is taken from the responses of 335 respondents; questionnaire is distributed to the owner and manager of Islamic small fashion business in Central Java-Indonesia. The finding shows that innovativeness and customer responsiveness can increase marketing performance through religio-centric market advantage. Religio-centric fashion advantage arises from innovation capability and customers' respond, and enables small businesses to increase marketing performance. By examining various literatures on resource-based view, market orientation, small business performance, entrepreneurship, and customer religiosity, this research offers a unique analysis about innovativeness and customers responsiveness as well as their impact on marketing performance in religious-based industry that receives less attention from researchers. Conceptual discussion and empirical result widen the previous research about innovation culture and customer orientation on small business becomes more specifically based on religion.
\end{abstract}

JEL classification: M21, M31, O31.

Keywords: Innovativeness; Customers responsiveness; Religio-centric fashion advantage; Marketing performance.

\footnotetext{
*Corresponding author:

E-mail address: hendar010263@yahoo.com (H. Hendar)

Peer Review under the responsibility of Universidad Nacional Autónoma de México.
} 


\section{Resumen}

Este estudio tiene como objetivo investigar y examinar el papel de la ventaja de la moda centrada en la religión en la mediación de la relación de capacidad de innovación y la capacidad de respuesta de los clientes con el rendimiento de marketing en la industria de la moda religiosa. El modelado de ecuaciones estructurales se usa para probar las hipótesis de investigación sobre la base de datos del negocio islámico de la moda en Indonesia. Los datos se tomaron de las respuestas de 335 encuestados; El cuestionario se distribuye al propietario y gerente del negocio de la moda islámica en Java Central, Indonesia. El hallazgo muestra que la capacidad de innovación y la capacidad de respuesta del cliente pueden aumentar el rendimiento de comercialización a través de una ventaja de mercado centrada en la religión. La ventaja de la moda centrada en la religión surge de la capacidad de innovación y la respuesta de los clientes, y permite a las pequeñas empresas aumentar el rendimiento de comercialización. Al examinar varias literaturas sobre visión basada en recursos, orientación al mercado, desempeño de pequeñas empresas, emprendimiento y religiosidad de los clientes, esta investigación ofrece un análisis único sobre la capacidad de respuesta y la capacidad innovadora de los clientes, así como su impacto en el desempeño de marketing en la industria religiosa que recibe menos atención de los investigadores.

Códigos JEL: M21, M31, O31.

Palabras clave: Innovación; Capacidad de respuesta de los clientes; Ventaja de la moda centrada en la religión; Rendimiento de la comercialización.

\section{Introduction}

Studies in INN and CRS regarding to marketing performance in religious-based industries, such as Muslim fashion in Indonesia, have attracted serious attention from academicians and practitioners. The Indonesian fashion world has reflected the lifestyle of modern society, following the trend, very fashionable, and fashion style which reflect that Indonesia is a Muslim country. Indonesia is a country with the largest Muslim population and the highest GDP (Gross Domestic Product) among Muslim countries (about 12.7 percent of the total Muslim in the world). The growing demand for Muslim clothing, the ever-growing hijab communities, and the implication of ever-growing religious activities enable Indonesia to be the qibla of world Muslim fashion in 2020. Indonesia has the potential to be one of the world's fashion centers, especially for Muslim fashion, as Indonesia has abundant creative resources and cultural heritage. In the future, Indonesia can be a source of inspiration for the development of world fashion (Nuraini, 2015). The other reasons are as follows, (1) various media have shown the attractiveness of Muslim fashion products that can affect consumer buying behavior, (2) the creativity of Muslim fashion designers has spawned a fashionable fashion model by not abandoning the element of adherence to religious norms, (3) the emergence of the trendsetter that the fashion model and style have inspired many consumers, (4) the absence of government obstacles to create Muslim fashion designs, as long as they do not break religious teachings, and (5) information technology support that allows entrepreneurs to create attractive and maneuverable products in the targeted market segments (Nuraini, 2015).

At the moment, small business fashion in Indonesia is facing a challenging change in a highly dynamic and uncertain business environment. Therefore, what has been designed at the beginning has become more difficult to implement. The pressure of change coming from the fast technological change, knowledge, culture, lifestyle, competition with similar products and 
substitution, the pace of innovation and others make the value added of products and services of each company eroded very quickly. The pressure of change requires continuous fundamental changes in the company's internal environment, including on how the company reconfigures its resources, continually innovates and reinforces its marketing capabilities to maintain positional excellence and improve its business performance (McGrath, 2013).

Fashion industry illustrates a product or market with the element of style that tends to persist in short time (Christopher et. al., 2004). Consumers in fashion industry have awareness of fashion that is likely to be stable, fast-changing and unpredictable, so the focus of competition in the industry has shifted from price and quality into competition in the form of time. In fashion market, it is very easy to copy a design, so the production only lasts for successful items (Barnes et.al., 2006; Barnes and Lea-Greenwood, 2006). In such market scope, there are three forms of resources capability that determine business performance, such as adaptive, absorptive, and innovative capabilities). Adaptive capability is the company's ability to identify and exploit developing market opportunities. This capability involves the company's ability to adapt to market-product scope for the purpose of responding to external opportunities; scanning market, monitoring customers and competitors, as well as allocating resources for marketing activities. Empirically, adaptive capability is identical with responsiveness to customers and competitors. Customer response capability relates to the company's ability and its resources to deliver value-added for customers (Pehrsson, 2011). Competitor response capabilities then relates to ability to understand the strengths and weaknesses of competitors' current and future strategies (Lewrick et. al., 2011).

Absorptive capability is the company's ability to recognize value and new external information, to assimilate and apply it in a form of commercialization (Wang and Ahmed, 2007). Absorptive capability is often reflected in INN and its ability to take advantage of new knowledge is important for innovative activities of the company. Innovative Capability (INN) is the company's ability to develop new products, new processes, new organizational and new markets through innovative aligning orientation (Alpay et.al., 2012).

The approaches of Innovativeness (INN) and Customer Responsiveness (CRS) are two types of approaches commonly used to predict the company performance. Some studies have shown that companies with good innovativeness have achieved success in improving the company performance (Carbonell and Rodriguez, 2006b; Lee, 2008; Lages et. al., 2009; Gunday et. al., 2011b; Ar, 2012; Wang and Wang, 2012; Atalaya et.al., 2013; Cheng et. al., 2014). Other research have also shown that companies with strong INN will have better ability to improve marketing performance (Johnson et.al., 2009; Al-Saed et.al., 2010; Al-Zyadaat et. al., 2012; Dibrell et.al., 2013; Karabulut, 2015). However, several studies have found different evidence that INN is not important driver for increasing marketing performance (Sandvik and Sandvik, 2003; Shergill and Nargundkar, 2005; Atuahene-Gima et. al., 2006; Yalcinkaya et. al., 2007; Fu et. al., 2008; Song et. al., 2011). In customer-based researches, some findings have shown that customer orientation culture to always be responsive to customers plays a major role in improving the company performance (Farrell and Oczkowski, 2002; Kropp et. al., 2006; Carbonell and Escudero, 2010; Chen-Ho Chao and Spillan, 2010; Chung, 2012; RojasMe'ndez and Rod, 2013). However, some other empirical findings demonstrate that the ability to respond to customer need changes do not give a better impact on company performance (Johnson et.al., 2009; Matanda and Ndubisi, 2009; Bodlaj, 2010; Dong et.al., 2013). 
The above exposition basically shows that although INN and CRS theoretically is a strategic way to increase MRP, but these two variables practically do not always produce better marketing performance. Some studies have suggested that in order to produce better marketing performance, INN should result competitive advantages or positional advantage at first (Carbonell and Rodriguez, 2006b; Wei and Wang, 2011; Ahmadi et. al., 2013). Other studies also suggest the importance of product excellence as mediation in the influence of CRS on marketing performance (Langerak et. al., 2004; Nakata et. al., 2006; Adis and Jublee, 2010). If it is applied to fashion industry it will be possible for religious-based fashion product excellence to mediate the relationship of INN and CRS with MRP. Such product has been culturally designed, manufactured and offered in accordance with the religion guidance. The awareness to use Muslim fashion based on religion norms is shaped by the values of personal belief or faith.

Therefore, the purpose of this study is to examine the mediation role of religio-centric fashion advantage in bridging the correlation between INN and CRS relationships with MRP. The findings are further expected to contribute to the development of Resource Advantage Theory (Hunt et al, 1995), especially in the religious-based market segment, and on the development of religious fashion small businesses in improving their performance.

\section{Conceptual Mapping of Religio-centric Fashion Advantage (RFA)}

Religious-based market segmentation strategy is one of strategies recommended in marketing management literature. This is because religion influences consumer behaviour in decision making (Mokhlis, 2008; Shah Alam et. al., 2011; Abdur Razzaque and Nosheen Chaudhry, 2013; Bakar et. al., 2013). In addition, consumers in a particular religious group will identify themselves based on their religious values and believe that their religion is more important or superior than other religions or religio-centric (Corsini, 1999). Religio-centric implies a combination of positive attitude towards group members of a religion and negative attitude towards group members of other religious (Sterkens and Anthony, 2008). Religiocentric in this term means religious sentiments based on exclusivity of belief that the fulfilment of one's interests should be based on the teachings of his religion (Ray, 1972). Members of religious groups affiliated with a particular religion will consider religious attributes of their religion better than attributes of other religious groups (Sterkens and Anthony, 2008).

One of marketers' tasks in religion-based market segment is to build a positional advantage by positioning proposition of religion values to achieve better marketing performance. Positional advantage is a relative value of marketing strategy results sent to the target market as alternative for actual customers (Morgan, 2012). This study uses religio-centric fashion advantage as product excellence in religious-based fashion industry. Religio-centric fashion advantage is a new concept from the synthesis of fashion product excellence concept and religio-centric concept. Religio-centric fashion advantage then is defined as excess of a product produced by a company rather than the competitor's product offered to religious-based market segment and exploiting the target market by offering products that are more aesthetic, fashionable and in line with religious norms. A well-designed product will offer functional and aesthetical benefits to consumers, can also be an important source of differentiation. Fashionable religious-based products (up-to-date) are growing in terms of design, colour, pattern, form, size and other features that have special attraction for customers. Besides, value adherence on religious norms becomes a key to success and a source of corporate advantage. 
The consideration then comes from the following three indicators. First, a well-designed product will offer functional and aesthetic benefits to the customers, which can be an important source of differentiation (Kotler et. al., 2009). In this case, an aesthetic design is the key of competitive advantage in the fashion market. Second, religion-based products are growing and following trend both in terms of model, color, style, shape, size and other features, and become more fashionable, This means that it follows the latest trend. The findings of research conducted by Latiff and Alam (2013), shows that women's interest in Muslimah clothing mainly because it is in the trend and their knowledge of Muslim clothing enriched by the spread of media that show the Muslim clothing. Third, the value of adherence to religious norms is the key to success and a source of corporate excellence. For example, in the Muslim fashion market, every marketed product must fulfill the element of Syariah compliance. Syariah provision for Muslim fashion is an obligation that must be obeyed because the dress code has been arranged based on Al-Qur' an and Sunnah, and against the rule will get direct sanction from Allah SWT.

\section{Hypotheses}

\section{Innovativeness and Religio-centric fashion advantage}

INN is one of company's strategic instruments in managing the operations of the target market in order to enter new markets, increasing sales or maintaining market share, facing the competitors' maneuver happening or obstructing new competitors to enter the market. It is an appropriate medium to build sustainable competitive advantage (Carbonell and Rodriguez, 2006a; Iyer et. al., 2006; Gunday et. al., 2011a; Alpay et. al., 2012). INN is part of entrepreneurial orientation that is interpreted as entrepreneurs' willingness to support creativity and experiment in introducing new products or services, novelty, technology leadership and $\mathrm{R} \& \mathrm{D}$ in developing new process (Lumpkin and Dess, 1996). Therefore, INN is a company's capacity in introducing several new processes, new products, new ideas in the organization and new marketing strategies (Jiménez-Jiménez and Sanz-Valle, 2011). INN is the company's willingness to be oriented to technological growth, new products, new services or product lines that are better in pursuing competitive advantage. Thus, innovation is the result of knowledge creation and organizational trust. INN illustrates changes on product or services that already exist, process, and technology by introducing the latest product features, offering exceptional performance, or changing the rules of competitive domain (Avlonitis and Salavou, 2007; Dibrell et. al., 2013). INN is an organizational culture, values and beliefs to implement innovation (Wong, 2012). Therefore, INN basically is attitude, behaviour, tendency, ability and creativity of an entrepreneur to seek and implement new ideas in order to create something new and unique. INN may occur in product development, organizational process, organizational strategy, organizational behaviour, and others.

INN has a close connection with competitive advantage. Naidoo (2010) finds that marketing innovation has very strong influence on competitive advantage. Abou-Moghli, et al (2012) concludes that innovation has a positive impact on competitive advantage. Marketing innovation becomes substantial driver in competitive advantage (Naidoo, 2010; Abou-Moghli et. al., 2012). Some other empirical studies has shown positive impact between product innovation and product positional advantage (Song and Noh, 2006; Wong, 2012; Huang and Tsai, 2014). Such relationship very possibly occurs in religious-based market segment, such as 
Muslim fashion. In this type of market, products that are developed based on religious values will have potential to achieve product positional advantage. For example, halal products made in accordance with the guidance of Islamic Syariah are products which are highly desired by Muslim consumers. The obligation for Muslim women to consume halal products can be a key factor of the company's existence in this business. Religious products which adhere to religion norms are created with aesthetic design and potential have potential to gain religio-centric product positional advantage in targeted market segments.

H1: INN has a positive impact on RFA.

\section{Customer responsiveness (CRS) and Religio-centric fashion advantage (RFA)}

CRS is part of customer orientation culture becomes important antecedent for competitive advantage (Narver and Slater, 1990), especially in the short term competitive advantage (D'Aveni et. al., 2010; McGrath, 2013). Customer-oriented company is a company that has ability to build good relationship with customers (Wang and Feng, 2012), promotes behavioural values and norms that put the customer as the main focus (Jaworski and Kohli, 1993; Slater and Narver, 2000; Wang and Feng, 2012). CRS is associated with various activities provide value-added for customers, such as adaptation of product or service, solution for customer problem, building relationship with customers (Pehrsson, 2011) and providing legitimate needs for customers in exact time (Chavosha et. al. (2011). According to Chavosha et. al. (2011), understanding the changing of customer needs and performing rapid fulfilment will enable a company to maintain competitive advantage. Besides, company's ability to respond to customer needs is one of success keys in a competitive market. Companies that are highly responsive to customers put optimal attempt to pay attention and find solutions to customer problems, strive to build relationship with customers, and pay attention to serving customization (Jaworski and Kohli, 1993; Jaworski et. al., 2000; Pehrsson, 2014). Thus, CRS is the company's ability to respond to customer requests as well as appropriately and quickly adapt to gain or maintain a competitive advantage in the market. In fashion industry, the company's ability to quickly and appropriately respond to changes in customer needs including product design, product motif variation, the type and quality of raw materials used, and product model is the best way to get better business performance. Bell-shaped temporal pattern of fashion showing both fast progress phase and regress phase ease consumers to find alternative style. In the beginning, a certain style is introduced by a small group of fashion leaders. After that, many imitators scramble to enter the short-term market. When people getting fed up with the style, each consumer began to adopt new behaviours by looking for alternative styles (Corneo and Jeanne, 1999).

CRS will enable the company to create and exploit external opportunities and develop durable advantage when it is combined with insight and agility (Hitt et. al., 2001). By emphasizing CRS, the company can achieve competitive advantage and high performance levels to build knowledge and gain reputation based on customer needs (Narver and Slater, 1990; Kohli et.al., 1993). A strong customer interaction capability is one of most important marketing capabilities that enable the company to use their resources to build customer relationship more intensively, as well as a tool to develop sustainable competitive advantage (Day, 1994). It means that the ability to respond to customers determines positional advantage in targeted market segments. In cultural context of market orientation, customer orientation in a form of company commitment and continuity in compiling information about customers (Slater and Narver, 1995) will allow 
the company to improve positional advantage in targeted market segments (Hunt and Morgan, 1995).

Regarding with customer response capability in the fashion industry, Fuentes and Quiroga (2009) explains that fashion is a widespread social phenomenon and cannot be avoided from modern life, hence changes in the appeal of fashion attributes will influence consumption behaviour of fashion customers. Therefore, the company's ability to offer product with several attributes that match with customer needs and desire is the key factor to increase positional advantage and success in fashion business. In religious-based fashion market, companies that are responsive to the need of religious customer, such as trying hard to produce products according to religious guidance, that are aesthetic and fashionable, will have greater opportunity to get an religio-centric fashion advantage.

\section{H2: CRS has a positive effect on RFA.}

\section{Innovativeness (INN) and Marketing performance (MRP)}

Marketing is a very dynamic process that marketing performance is a multidimensional process involving adaptability (organizational ability to respond to environmental changes), effectiveness (the extent to which the organizational goals and objectives can be achieved), and efficiency (performance result ratio and the inputs needed to achieve) (Morgan et. al., 2002; Gao, 2010). Normatively, marketing performance measurement involves assessment on marketing resources (e.g. financial, physical, legal, organizational, reputation, relational) and capabilities (e.g. individual ability, specificity, functional and organizational) as sources of advantage; the achievement of positional advantage (e.g., excellence of product, service, price, cost, image and delivery), market performance (e.g., customer perception and behaviour post-purchase (customer perspective) and unit sales, market share, and others (the company's perspective) and financial performance (such as earnings, cash flow, and profits). Other researchers define marketing performance as the company's achievements in achieving the goals of market share, sales growth, improvement in new customers and retaining existing customers (Merrilees et. al., 2011; Prasertsang and Ussahawanitchakit, 2011); Soliman (2011). Therefore, this study conceptualizes marketing performance as a combination of the results of marketing activities perceived by the owner or manager of the company about achieving sales growth, sales volumes, sales targets, and customer growth.

INN is one way taken by a company to gain or maintain a competitive advantage and advance performance of the company. Several empirical studies have shown that innovation affect the company performance (Alpay et.al., 2012; Sok et.al.,2013). Other researchers show that marketing innovation positively impact marketing performance (Ar and Baki, 2011; AlZyadaat et.al.,2012). Besides, many studies have shown that product innovation has significant effect on business performance. For example, Matzler et. al. (2008) and Akgün et. al. (2009) find that profitability performance and growth performance in small and medium enterprises are determined by product innovation. Research in Asian countries conducted by Rosli and Sidek (2013) in Malaysia and Lee (2008) in Taiwan also shows that product innovation really becomes decisive factor for improving corporate performance.

The existence of real relationship between INN and company marketing performance shows that the tendency of companies to produce new and unique product will enable the company to improve its marketing performance. In religious-based market segment, the tendency very 
possibly occurs. Popular culture influences consumer behaviour about fashion product, and company's agreement to always produce new products and services based on customers desire will ease it achieving superior marketing performance.

H3: INN has a positive effect on MRP.

\section{Customers responsiveness (CRS) and Marketing performance (MRP)}

The linkage between CRS and MRP can refer to the view of Narver and Slater (1990), which shows that market orientation really becomes a strong driving for the improvement of company performance. Customer-oriented company is a company that is responsive to customers. The company will have a strong commitment to customers, add value for customers, meet the customer needs, aim to satisfy customers, constantly measure the customer satisfaction, and perform post-sales services. Companies with customer responsiveness have bigger opportunity to improve the company performance, including marketing performance (Chen-Ho Chao and Spillan, 2010; Chung, 2012).

Above empirical findings confirm that the company's marketing performance improvement depends on CRS. It is very likely applied in specific market, such as Muslim fashion market. The existence of Islamic guidance to keep silaturrahim (keep-in-touch) and build the kinship, requires the company to provide the best service to its customers. Companies with such capabilities have potential to improve their marketing performance in the form of sales revenue, sales volume, sales territories, achievement of sales targets, and market share.

H4: CRS has a positive effect on MRP.

Religio-centric fashion advantage (RFA) and Marketing performance (MRP)

Product excellence is a key factor of the success of new products and organizational performance. Many studies have shown that product benefit has a positive impact on company performance (Hsieh, et al., 2008). The previous researchers have shown the close relationship between product benefit and company's performance (Nakata et al., 2006; Hsieh et al., 2008; Ledwith and O'Dwyer, 2008). These conceptual and empirical evidences have shown consistently that product excellence is the most important characteristic in explaining the product's success or the product's performance. In some studies, product performance is presented through marketing performance embodied in the growth of sales and market share. This indicates that positional advantage is a decisive factor for product marketing performance. Thus, on a very specific fashion market segment as religious-based fashion, religio-centric fashion advantage will have potential to increase MRP.

H5: RFA has a positive effect on MRP.

\section{The Mediation Role of Religio-centric Fashion Advantage (RFA)}

As showned above, INN is an entrepreneurial orientation dimension that enables companies to act opportunistically (Lumpkin and Dess, 1996) and increase the capabilities of its resources to achieve product excellence (Huang and Tsai, 2014). On the other side, customer orientation culture allows the company to be always responsive to changing customer needs and enhance 
the capabilities of its resources to achieve product excellence (Langerak et al., 2004; Nakata et al., 2006; Adis and Jublee, 2010). Meanwhile, product excellence is perceived as a superior product that boost the competitiveness of products, which in turn will bring in much more income or profit for the company (Wong, 2012; Huang and Tsai, 2014). Thus, this study further elaborates that on religious-based market segments, religio-centric product advantage mediates the relationship between INN and CRS with MRP. In other words, beside that INN and CRS directly give effect on marketing performance, both of these variables may also indirectly affect the marketing performance through the mediation of religio-centric product advantage. In religious-based fashion market, it is very possible that the relationship of INN and CRS with MRP is mediated by RFA.

H6: RFA mediates the positive influence of INN on MRP.

H7: RFA mediates the positive influence of CRS on MRP.

\section{Research Method}

\section{Sample and procedure}

The population in this study is the owner and manager of small businesses in the Indonesian Muslim fashion that according to Law No. 20 of 2008 have most net worth $500,000,000$ or have annual sales turnover of IDR 2.5 billion. The data obtained from questionnaires distributed to 427 respondents in 11 regencies/ cities in Central Java, Indonesia. The questionnaires are submitted by officers who get advanced training on fashion small business owners or to people who are entrusted in small business. After 3 months of data collection process, only 406 of them are returned, or about $81.03 \%$. The final evaluation after examining the questionnaires, out of the damaged and data outliers, there are 335 questionnaires $(78.45 \%)$ were decent to use for data analysis. Non-response bias test has been conducted to determine the consistency of answers from respondents who collect directly or less than one month with those who collect them more than one month. The test results show that respondents who answered directly or less than one month did not differ significantly with those who collect them more than one month. The selected respondents consist of $76.7 \%$ women and $23.3 \%$ men between 25 to 50 years old. Most of them are the owners and managers of small businesses at Moslem fashion who have family and worked for more than three years. Their level of education mostly $(65.1 \%)$ is high school or earlier and $10.7 \%$ of them are diploma, while $24.2 \%$ of them are Bachelor.

\section{Instrument}

Two exogenous variables used in this study are INN and CRS. INN is adapted from the views of Lumpkin and Dess (1996). INN is an entrepreneur tendency to seek and implement new ideas in order to create something new and unique. CRS is adapted from the view of Chavosha, et al. (2011) and Daugherty, et al.(1995). CRS is a company's ability to respond to customer requests and to adapt appropriately and quickly to gain or maintain the competitive advantage in the market. RFA is a new concept of positional advantages synthesizing derived from RBV approach and religio-centric concept derived from Social Identity Theory. The concept is then defined as the excess of a fashion product rather than the competitor's company product because the products offered have more aesthetic design, more fashionable and more obedient to religious norms. MRP is adapted from Merrilees et al. (2011) and Healy, et al. 
(2014) which is a combination of the results of marketing activities perceived by the company owners or managers. Four items of questionnaire is used to measure INN, five items is used to measure CRS, three items is used to measure RFA, and four item is used to measure MRP (see Table 1). Measurement of each instrument uses interval scale 1 to 10 , score 1 shows strongly disagree of a proposed question and score 10 shows strongly agree.

\section{Analysis technique}

Structural Equation Modelling (SEM) is used to test the model of empirical research using data from small business owners or managers of Islamic fashion in Central Java, Indonesia. Confirmatory Factor Analysis Model is used to test the multidimensionality of a theoretical construct (construct validity test). In addition, SEM is also used as a comprehensive test tool for full structural models. The data analysis follows the process recommended by Hair, et al. (2010). First, creating diagram track model of causality among constructs and its indicators. Second, testing un-dimensionality of each construct uses confirmatory factor analysis. Third, estimating the equation of full structural model for indicators passed in the confirmatory test. Fourth, discussing discriminant convergence and validity before moving to substantive analysis. SEM analysis is performed using software versions Amos 22:00.

\section{Findings}

This study reports the result of Confirmatory Factor Analysis (CFA) for the complete sample. Observations are performed on 16 indicators (4 indicators of INN, 5 indicators of CRS, 3 indicators of RFA and 4 indicators of MRP to get 16 relevant values of loading factor $(\lambda 1$ $\lambda 16)$. Un-dimensional rating is done through examination of estimation on general least square standardized estimates factor loading, which exceeds 0.6 (Hair et al., 2010). In accordance with the provisions contained in AMOS, loading factor for all latent variables observed have good validity because it has value above 0.6 (Table 1 ).

Table 1

Confirmatory Factor Analysis Results for the Measurement Model ${ }^{\mathrm{a}}$

\begin{tabular}{|c|c|c|}
\hline Innovativeness (INN) & $\lambda$ & p-value \\
\hline Openness of marketing ideas & 0.821 & 0.000 \\
\hline Frequency to try new marketing breakthroughs & 0.627 & 0.000 \\
\hline Continuity in product appearance improvement & 0.734 & 0.000 \\
\hline Novelty of product model & 0.738 & 0.000 \\
\hline \multicolumn{3}{|l|}{ Customers Responsiveness (CRS) } \\
\hline Ability to quickly respond to product design needs & 0.731 & 0.000 \\
\hline Ability to quickly respond to product motif needs & 0.767 & 0.000 \\
\hline Ability to quickly respond to raw material needs & 0.782 & 0.000 \\
\hline Ability to quickly respond to product model needs & 0.788 & 0.000 \\
\hline Ability to accurately respond to product demands & 0.752 & 0.000 \\
\hline \multicolumn{3}{|l|}{ Religio-centric Fashion Advantage (RFA) } \\
\hline More aesthetic in religious product design & 0.765 & 0.000 \\
\hline ore fashionable in religious product trend & 0.791 & 0.000 \\
\hline More adhere with religious norms & 0.67 & 0.000 \\
\hline \multicolumn{3}{|l|}{ Marketing Performance (MRP) } \\
\hline Growth of sales outcome in the last 3 years & 0.763 & 0.000 \\
\hline Improvement of sales volume in the last 3 years & 0.721 & 0.000 \\
\hline Achievement of sales targets in the last 3 years & 0.635 & 0.000 \\
\hline Improvement of customer number in the last 3 years & 0.710 & 0.000 \\
\hline
\end{tabular}


The high construct reliability demonstrates internal consistency, which means that the indicator has consistently represented the same latent constructs (Hair et al., 2010). Construct Reliability (CR) that exceeds 0.7, Variance Extracted (VE) that exceeds 0.5 and Discriminant Validity (DV) that exceeds 0.7 are standard measurement of internal consistency of the indicators used. Table 2 shows the value of CR is higher than 0.7, VE exceeds 0.5 and DV that exceeds 0.7 for INN, CRS, RFA and MRP indicate that each instrument has good validity in explaining the research variables.

Table 2

Construct Reliabilities, Correlations and AVE

\begin{tabular}{lllll}
\hline $\mathbf{N}=\mathbf{3 3 2}$ & $\mathbf{1}$ & $\mathbf{2}$ & $\mathbf{3}$ & $\mathbf{4}$ \\
\hline Innovativeness (INN) & $\mathbf{0 . 8 2 3}^{\mathrm{a}}$ & & & \\
Customers Responsiveness (CRS) & 0.516 & $\mathbf{0 . 8 7 5}$ & & \\
Religio-centric Fashion Advantage (RFA) & 0.665 & 0.543 & $\mathbf{0 . 8 1 8}$ & \\
Marketing Performance (MRP) & 0.538 & 0.511 & 0.732 & $\mathbf{0 . 8 0 1}$ \\
\hline Average Variance Extracted (AVE) & 0.845 & 0.897 & 0.854 & 0.818 \\
\hline
\end{tabular}

a Factor reliabilities are on the diagonal (italic bold).

The test results of full model of structural equation shows good Goodness-of-Fit index because it produces criteria that are in accordance with SEM recommendation. The value $\square^{2}$ 107.809 is not significant at $\alpha 0.05$, GFI index 0.960 , AGFI 0.944 , TLI 0.965 , CFI 0.972 that is equal or exceed 0.90 and other criteria, such as RMSEA 0.017 less than $0.08, \mathrm{CMIM} / \mathrm{DF} 1.100$ less than 2, and the value Hoetler01 (414) that exceeds the amount of sample (335) suits with recommended criteria in SEM. This shows that the recommended model fits or has eligibility to examine the relationship among variables.

Table 3

Parameter estimates for the path: direct effects

\begin{tabular}{lllll}
\hline Regression & Std B & Unstd B & S.E. & C.R. \\
\hline INN à RFA & 0.524 & 0.480 & 0.078 & $6.629^{* *}$ \\
CRS à RFA & 0.273 & 0.255 & 0.066 & $3.882^{* *}$ \\
INN à MRP & 0.196 & 0.161 & 0.086 & $2.082^{*}$ \\
CRS à MRP & 0.225 & 0.189 & 0.063 & $3.011^{* *}$ \\
RFA à MRP & 0.341 & 0.306 & 0.078 & $3.512^{* *}$ \\
INN à RFA à MRP & -- & 0.147 & 0.046 & $3.210^{* *}$ \\
CRS à RFA à MRP & -- & 0.078 & 0.028 & $3.774^{*}$ \\
\hline
\end{tabular}

Note: $* \mathrm{p}<0.05 ; * * \mathrm{p}<0.01$ 
Table 3 and Figure 1 show the result of direct effect of significant positive effect between INN and RFA (Std $\beta=0524$, c.r. $=6,629$, p-value $<0.01$ ), between CRS and RFA (Std $\beta=$ 0273, $\mathrm{cr}=3.210, \mathrm{p}$ value $<0: 01)$, between INN and MRP $(\operatorname{Std} \beta=0196$, c.r. $=2.082$, p-value $<0.05)$, between CRS and MRP $(\operatorname{Std} \beta=0.225$, c.r. $=3,011$, p-value $<0.01)$, and between RFA and MRP $(\operatorname{Std} \beta=0366$, c.r. $=3,790, p<0: 01)$. This indicates that hypotheses H1, H2, H3, H4, and $\mathrm{H} 5$ are accepted.

Mediation test procedure proposed by Sobel (1982) is adopted to test the mediating effect of RFA. Regarding to the H6 and H7, Sobel test of both antecedents affect MRP through RFA, especially, RFA roles as a full mediation in the relationship between INN and MRP. The direct effect of INN on RFA is showned by Unstd $\beta 0.480$, S.E 0.078 and c.r 6.629 , so it is significant at $\alpha 0.01$. The immediate effect of MRP on RFA is presented by Unstd $\beta 0.306$, S.E 0.078 and c.r 3.512, so it is significant at $\alpha$ 0.01. Indirect effect of MRP on RFA though INN is indicated by coefficient Unstd $\beta 0.147(0.480 \times 0.360)$. The result of Sobel test shows the value of c.r. 3.210 , S.E 0.046 and p-value 0.001 , so it is significant at $\alpha 0.01$. The total effect of the influence of INN on MRP through RFA is $0.308(0.161+0.147)$ which is higher than the direct effect (0.161) shows that RFA has a very important role as mediation in the relationship of INN with MRP and becomes a substantial alternative to improve marketing performance. Therefore, this study accepts Hypothesis 6 (H6).

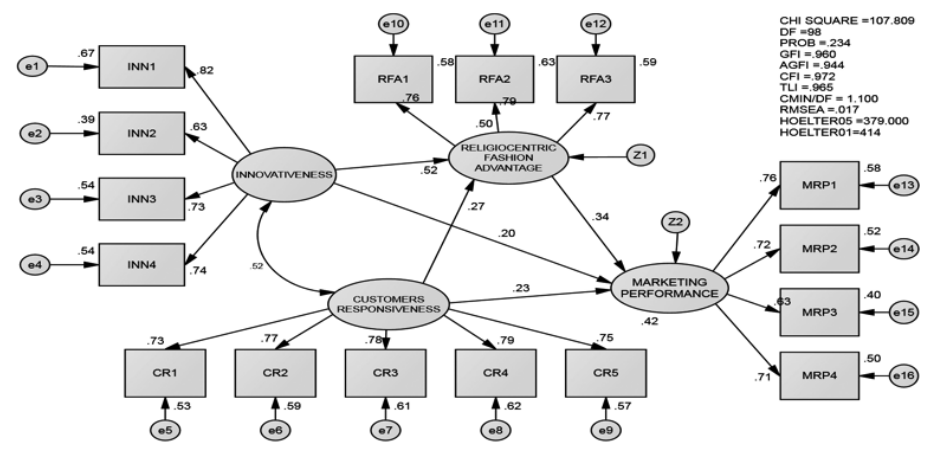

Figure 1. Result of empiric model test.

In addition, RFA also mediates the relationship of CRS and MRP. The direct effect of CRS on RFA is showned by Unstd $\beta 0.225$, S.E 0.066 and c.r. 3.882, so it is significant at $\alpha 0.01$. The immediate effect of RFA on MRP is presented by Unstd $\beta$ 0.306, S.E 0.078 and c.r. 3.512, so it is significant at $\alpha 0.01$. The indirect effect of CRS on MRP through RFA is indicated by coefficient Unstd $\beta 0.078$ (0.225 x 0.360). The result of Sobel Test shows c.r. 2.774, S.E 0.028 and p-value 0.028 , so it is significant at $\alpha 0.05$. The total effect of the influence of CRS on MRP through RFA with value $0.267(0.189+0.147)$ which is higher than the direct effect $(0.189)$ shows that RFA has a very important role as mediation in the relationship between CRS and MRP, and becomes an important alternative to improve marketing performance. Therefore, hypotheses $\mathrm{H} 7$ is accepted in this study. 


\section{Conclusion}

This study aims to investigate the relationship between INN and CRS with RFA and MRP, as well as the mediating role of RFA in relationship of INN and CRS with MRP. This study has shown how important the role of RFA for companies engaging in religious-based fashion industry that is very dynamic and has characteristic of short life cycle, unstable demand, low predictability and high level of impulse purchasing (Christopher et al., 2004). RFA has been a convincing mediator in the relationship between INN and CRS with marketing performance. This study has given new reference that provides solutions to controversy of the relationship of INN and CRS with MRP. The results have confirmed the role of internal factors in strengthening RFA. As internal driver of RFA, INN and CRS will arise if a company has innovation culture and strong customer orientation culture. Strong innovation culture allows all components of the company work hard in finding new ideas that drive business progress, trying new ways that are beneficial for business advancement, continually improving the product appearance, and constantly renewing offered product model. While the culture of customer orientation enables all components in the company strive to improve their capabilities in responding to changing in customer needs. In Muslim fashion industry, the ability to respond quickly and appropriately on changing needs of design, motif, model and raw material is most essential to maintain positional advantage and MRP improvement.

The test results have shown that the higher INN of a company in religious-based market segments, the higher RFA of the company will be. In general, these findings complement the view of resource-based view (RBV) and resource advantage theory (R-A Theory) about the substantial role of resources and capabilities (especially innovation) in gaining competitive advantage or positional advantage and superior performance in a competitive market (Barney, 1991; Hunt and Morgan, 1995; Morgan, 2012; Ahmadi et al., 2013). This result is in line with Abou-Moghli et al. (2012), Cascio (2011), and Naidoo (2010) who find a big role of innovation in the formation of positional advantage in a highly dynamic environment.

The test results have also proved that the more responsive a company on customer changing needs and desires in religious-based market segments, the higher the RFA will be. The results of this study confirm previous findings about the relationship between customer orientation and competitive advantage or positional advantage (Hunt and Morgan, 1995; Langerak et al., 2004; Zhou et al., 2009; Adis and Jublee, 2010; Al-alak and Tarabieh, 2011). In addition, the results of this study enrich RBV theory about the role of entrepreneur resources and capabilities in developing competitive advantage. CRS will enable companies to create and exploit external opportunities and develop durable excellence when it is combined with insight and agility (Hitt et al., 2001). In the context of customer orientation culture, the company's ability in accumulating information of changing customer needs and reacting quickly and appropriately to these changes will enable the company to improve positional advantage in the targeted market segments (Hunt 1995).

The results of this study also prove that the higher the company's RFA in a religious-based market segment, the higher the company's MRP will be. In general, the results of this study agree with some previous research findings about the relationship of competitive advantage and the company performance, such as in the researches of Agha and Alrubaiee (2012), Zhou et. al. (2009), and Kamukama et. al. (2011). These findings also agree with several previous studies which show the relationship of product positional advantage and company performance 
(Langerak et. al., 2004; Carbonell and Rodriguez, 2006b); Hsieh et. al. (2008); Leonidou et. al. (2011).

However, different from the results of previous studies as have been mentioned above, this study analyze more specifically on the influence of INN and CRS on MRP in religious-based industry. The addition of religio-centric concept on positional advantage concept is new and has extended their knowledge about RBV and R-A Theory in religious-based industry. On religious-based market segments, INN and company's ability to focus on the fulfilment of customer religiosity needs by offering new religious products that are aesthetic, fashionable and obedient to religious norms will enable the company to achieve better religio-centric fashion advantage. Thus, on religious-based market segments, the company that has a strong religiocentric fashion advantage will have better potential in gaining superior MRP.

According to structural model analysis, as a whole INN and CRS have direct impact on religio-centric fashion advantage and MRP. INN and CRS also have indirect effect on MRP through religio-centric fashion advantage. These test results clearly prove that religio-centric fashion advantage has important role to overcome the research gap regarding to the effect of INN and CRS on MRP. In other words, companies with better INN and CRS in resulting religio-centric fashion advantage will result better marketing performance. In particular, INN contributes to religio-centric fashion advantage, which in turn can increase MRP. Being consistent with the researches of (Carbonell and Rodriguez, 2006b; Wei and Wang, 2011; Ahmadi et. al., 2013), this study further confirm the mediating role of religio-centric fashion advantage in the relationship of INN and MRP which is neglected in the studies of (Johnson et. al., 2009; Acar and Acar, 2012; Dibrell et. al., 2013). In addition, CRS also contributes to religio-centric fashion advantage, which in turn will increase MRP. Consistent with the research of (Langerak et.al., 2004; Wei and Wang, 2011), this study further confirms the mediating role of religio-centric fashion advantage in the relationship of CRS and MRP which is neglected in the study of (Chavosha et. al., 2011; Pehrsson, 2014; Wei et.al., 2014).

\section{Limitations and future research directions}

Previous research has put product excellence as mediating variable for the relationship of INN and CRS with MRP. This research has been more specific by placing INN as part of entrepreneurial orientation, CRS as part of market orientation, RFA as part of competitive advantage, and MRP as part of company performance. Meanwhile, in-depth research on other dimensions about the role of product excellence antecedent variables such as the role of technological resource and capability that receive attention from Ahmadi et al. (2013), the competitor respond capability (Zhou et al., 2009), another dimension of entrepreneurial orientation, such as risk taking and proactiveness (Wong, 2012), social capital (Chang, et al., 2010) and quality and stability requirements (Yang et al,2014) that have not been performed. In the future, testing on the role of these variables in improving RFA and MRP are still needed for the development of marketing management science.

Previous researches have put internal variable to mediate the relationship of INN and CRS on MRP, such as product benefits (Langerak et al., 2004), innovation performance (Bodlaj 2010), and competitive advantage (Zhou et al., 2009). Meanwhile, the placement of variables in external context consisting of market dynamic, competition intensity and market growth, moderate the relationship of INN and CRS on business performance. External variables can be used to add our model and test its impact on the relationship of INN and CRS on marketing 
performance. In addition, the types of business strategies also affect the relationship of INN and CRS on performance marketing. Therefore, future studies can include the type of business strategy in our model to examine the relationship of INN and CRS on with MRP.

\section{References}

Abdur Razzaque, M. and S. Nosheen Chaudhry (2013). "Religiosity and Muslim consumers' decision-making process in a non-Muslim society". Journal of Islamic Marketing. 4. 2. 198-217. https://doi.org/10.1108/17590831311329313

Abou-Moghli, A. A., G. M. A. Abdallah and A. A. Muala (2012). "Impact of Innovation on Realizing Competitive Advantage in Banking Sector in Jordan”. American Academic \& Scholarly Research Journal. Vol. 4. No. 5, Sept. 2012.

Acar, A. Z. and P. Acar (2012). "The effects of organizational culture and innovativeness on business performance in healthcare industry". Procedia - Social and Behavioral Sciences. Vol. 58 (2012). pp. 683 - 692. https://doi. org/10.1016/j.sbspro.2012.09.1046

Adis, A.-A. A. and E. Jublee (2010). "Market orientation and new product performance: The mediating role of product advantage". African Journal of Marketing Management. Vol. 2. No. 5 (August 2010). pp. 91-100.

Agha, S. and L. Alrubaiee (2012). "Effect of Core Competence on Competitive Advantage and Organizational Performance". International Journal of Business and Management. Vol. 7. No 1. pp. 192 - 204. https://doi.org/10.5539/ ijbm.v7n1p192

Ahmadi, H., A. O’Cass and M. P. Miles (2013). "Product resource-capability complementarity, integration mechanisms, and first product advantage". Journal of Business Research. xxx (2013) pp. 1-6. https://doi.org/10.1016/j. jbusres.2013.11.031

Akgu"n, A. E., H. Keskin and J. Byrne (2009). "Organizational emotional capability, product and process innovation, and firm performance : An empirical analysis". Journal of Engineering and Technology Management. 26 (2009). pp. 103 - 130. https://doi.org/10.1016/j.jengtecman.2009.06.008

Al-Saed, R., R. P and A. Upadhya (2010). "Entrepreneurial Orientation, Knowledge Process, and Marketing Performance An investigation in small organizations in Sharjah Emirate ". Journal of Asia Entrepreneurship and Sustainability. Vol VI. Issue 2.

Al-Zyadaat, M. A., M. A. Saudi and M. A. Al-Awamreh (2012). “The Relationship Between Innovation and Marketing Performance in Business Organizations: An Empirical Study on Industrial Organizations in the Industrial City of King Abdullah II". International Business and Management. Vol. 5. No. 2. pp. 76-84.

Alpay, G., M. Bodur, C. Yilmaz and P. Buyukbalci (2012). "How does innovativeness yield superior firm performance ? The role of marketing effectiveness". Innovation : Management, policy \& practice. Volume 14. Issue 1. pp. 107 - 128. https://doi.org/10.5172/impp.2012.14.1.107

Ar, I. M. (2012). "The impact of green product innovation on firm performance and competitive capability: the moderating role of managerial environmental concern". Procedia - Social and Behavioral Sciences. Vol. 62 ( 2012 ). pp. 854 - 864. https://doi.org/10.1016/j.sbspro.2012.09.144

Ar, I. M. and B. Baki (2011). "Antecedents and performance impacts of product versus process innovation. Empirical evidence from SMEs located in Turkish science and technology parks". European Journal of Innovation Management. Vol. 14 No. 2. pp. 172-206. https://doi.org/10.1108/14601061111124885

Atalaya, M., N. Anafarta and F. Sarvanc (2013). "The relationship between innovation and firm performance: An empirical evidence from Turkish automotive supplier industry". Procedia - Social and Behavioral Sciences. Vol. 75 (2013). pp. 226- 235. https://doi.org/10.1016/j.sbspro.2013.04.026

Atuahene-Gima, K., H. Li and L. M. De Luca (2006). "The contingent value of marketing strategy innovativeness for product development performance in Chinese new technology ventures”. Industrial Marketing Management. 35. 3. 359-372. https://doi.org/10.1016/j.indmarman.2005.05.017

Avlonitis, G. J. and H. E. Salavou (2007). "Entrepreneurial orientation of SMEs, product innovativeness, and performance”. Journal of Business Research. Vol. 60 (2007). pp. 566-575. https://doi.org/10.1016/j.jbusres.2007.01.001

Bakar, A., R. Lee and C. Rungie (2013). "The effects of religious symbols in product packaging on Muslim consumer responses”. Australasian Marketing Journal 21 (2013) 198-204. https://doi.org/10.1016/j.ausmj.2013.07.002 
Barnes, L., S. G. Hayes and N. Jones (2006). "Fast fashion: a financial snapshot". Journal of Fashion Marketing and Management: An International Journal. 10. 3. 282-300. https://doi.org/10.1108/13612020610679277

Barnes, L. and G. Lea-Greenwood (2006). "Fast fashioning the supply chain: shaping the research agenda". Journal of Fashion Marketing and Management: An International Journal. 10. 3. 259-271. https://doi. org/10.1108/13612020610679259

Bodlaj, M. (2010). "The impac of a responsive and proactive market orientation on innovation and business performance”. ECONOMIC AND BUSINESS REVIEW. Vol. 12. No. 4. pp. 241-261.

Carbonell, P. and A. I. R. g. Escudero (2010). "The effect of market orientation on innovation speed and new product performance “. Journal of Business \& Industrial Marketing. Vo. 25 (2010). No. 7. pp. 501-513. https://doi. org/10.1108/08858621011077736

Carbonell, P. and A. I. Rodriguez (2006a). "The impact of market characteristics and innovation speed on perceptions of positional advantage and new product performance ". International Journal of Research in Marketing. 23. 1. 1-12. https://doi.org/10.1016/j.ijresmar.2006.01.002

Chavosha, A., A. B. Halimi, S. Soheilirad, A. Ghajarzadeh and A. Nourizadehe (2011). "Customer Responsiveness and Export Performance of Selected Electronic Equipment Export Companies in Malaysia". International Conference on Social Science and Humanity. Vol. 5. pp. 124-127.

Chen-Ho Chao, M. and J. E. Spillan (2010). "The journey from market orientation to firm performance". Management Research Review. 33. 5. 472-483. https://doi.org/10.1108/01409171011041901

Cheng, C. C. J., C.-1. Yang and C. Sheu (2014). "The link between eco-innovation and business performance: a Taiwanese industry context". Journal of Cleaner Production. Vol. 64 pp. 81-90. https://doi.org/10.1016/j.jclepro.2013.09.050

Christopher, M., R. Lowson and H. Peck (2004). "Creating agile supply chains in the fashion industry”. International Journal of Retail \& Distribution Management. 32. 8. 367-376. https://doi.org/10.1108/09590550410546188

Chung, H. F. L. (2012). "Export market orientation, managerial ties, and performance". International Marketing Review. Vol. 29. No. 4. pp. 403 - 423. https://doi.org/10.1108/02651331211242638

Corneo, G. and O. Jeanne (1999). "Segmented communication and fashionable behavior". Journal of Economic Behavior \& Organization. Vol. 39 (1999). pp. 371-385. https://doi.org/10.1016/s0167-2681(99)00046-3

Corsini, R. J. (1999). "The Dictionary of Psychology". Psychology Press.

D'Aveni, R. A., G. B. Dagnino and K. G. Smith (2010). "The Age of Temporary Advantage". Strategic Management Journal. Vol. 31. pp. 1371 - 1385. https://doi.org/10.1002/smj.897

Day, G. S. (1994). “The Capabilities of Market-Driven Organizations”. Journal of Marketing. Vol. 58 (October 1994). pp. 37 - 52. https://doi.org/10.2307/1251915

Dibrell, C., J. B. Craig and D. O. Neubaum (2013). "Linking the formal strategic planning process, planning flexibility, and innovativeness to firm performance". Journal of Business Research. xxx (2013). No. pp. 8. https://doi. org/10.1016/j.jbusres.2013.10.011

Dong, X., C. Andrew Hinsch, S. Zou and H. Fu (2013). "The effect of market orientation dimensions on multinational SBU's strategic performance". International Marketing Review. 30. 6. 591-616. https://doi.org/10.1108/imr-122011-0284

Farrell, M. A. and E. Oczkowski (2002). "Are Market Orientation and Learning Orientation Necessary for Superior Organizational Performance?”. Journal of Market - Focused Management.

Fu, F. Q., E. Jones and W. Bolander (2008). "Product Innovativeness, Customer Newness, And New Product Performance: A Time-Lagged Examination Of The Impact Of Salesperson Selling Intentions On New Product Performance”. Journal of Personal Selling \& Sales Management. vol. XXVIII. 4. pp. 351-364. https://doi.org/10.2753/ pss0885-3134280402

Gao, Y. (2010). "Measuring marketing performance: a review and a framework". The Marketing Review. Vol. 10 (2010). No. 1. https://doi.org/10.1362/146934710x488924

Gunday, G., G. Ulusoy, K. Kilic and L. Alpkan (2011a). "Effects of innovation types on firm performance". Int. J. Production Economics. Vol. 133. pp. 662-676. https://doi.org/10.1016/j.ijpe.2011.05.014

Hitt, M. A., R. D. Ireland and R. E. Hoskisson (2001). "Strategic Management : Competitiveness and Globalization. 4th Edition. South-Western College Publishing.". 
Hsieh, M.-H., K.-H. Tsai and J.-R. Wang (2008). "The moderating effects of market orientation and launch proficiency on the product advantage-performance relationship". Industrial Marketing Management. Vol. 37 (2008). pp. 580-592. https://doi.org/10.1016/j.indmarman.2007.03.003

Huang, C.-T. and K.-H. Tsai (2014). "Synergy, environmental context, and new product performance: A review based on manufacturing firms". Industrial Marketing Management xxx (2014) xxx-xxx. https://doi.org/10.1016/j. indmarman.2014.06.010

Hunt, S. D. and R. M. Morgan (1995). “The Comparative Advantage Theory of Competition”. Journal of Marketing. Vol. 59 (April 1995). pp. 1-15. https://doi.org/10.2307/1252069

Iyer, G. R., P. J. LaPlaca and A. Sharma (2006). "Innovation and new product introductions in emerging markets: Strategic recommendations for the Indian market”. Industrial Marketing Management. 35. 3. 373-382. https://doi. org/10.1016/j.indmarman.2005.02.007

Jaworski, B., A. K. Kohli and A. Sahay (2000). "Market-driven versus driving markets". Academy of Marketing Science. Vol. 28 (Winter 2000). No. 1. pg. 45-54. https://doi.org/10.1177/0092070300281005

Jaworski, B. J. and A. K. Kohli (1993). "Market Orientation : Antecendens and Consequences". Journal of Marketing. Vo. 57 (Juli 1993). pp. 53 - 70. https://doi.org/10.2307/1251854

Jiménez-Jiménez, D. and R. Sanz-Valle (2011). "Innovation, organizational learning, and performance". Journal of Business Research. Vol. 64 (2011). pp. 408-417.

Johnson, A. J., C. C. Dibrell and E. Hansen (2009). "Market Orientation, Innovativeness, and Performance of Food Companies". Journal of Agribusiness. Vol. 27. No. 1/2. pp. 85-106.

Kamukama, N., A. Ahiauzu and J. M. Ntayi (2011). "Competitive advantage: mediator of intellectual capital and performance”. Journal of Intellectual Capital. 12. 1. 152-164. https://doi.org/10.1108/14691931111097953

Karabulut, A. T. (2015). "Effects of Innovation Types on Performance of Manufacturing Firms in Turkey". Procedia Social and Behavioral Sciences. 195. 1355-1364. https://doi.org/10.1016/j.sbspro.2015.06.322

Kohli, A. K., B. J. Jaworski and A. Kumar (1993). "MARKOR : A Measure of Market Orientation”. Journal of Marketing Research. Vol. 30. No. 4 (Nov., 1993). pp. 467-477.

Kotler, P., K. L. Keller and B. S. (Penerjemah) (2009). “Manajemen Pemasaran. Edisi 13. Jilid II.”. Penerbit Erlangga. Jakarta.

Kropp, F., N. J. Lindsay and A. Shoham (2006). "Entrepreneurial, market, and learning orientations and international entrepreneurial business venture performance in South African firm". International Marketing Review. Vol. 23 No. 5, 2006, pp. 504-523, qEmerald Group Publishing Limited, 0265-1335. https://doi. org/10.1108/02651330610703427

Lages, L. F., G. Silva and C. Styles (2009). "Relationship Capabilities, Quality, and Innovation as Determinants of Export Performance”. Journal of International Marketing. 2009, American Marketing Association, Vol. 17, No. 4, 2009, pp. 47-70. https://doi.org/10.1509/jimk.17.4.47

Langerak, F., E. J. Hultink and H. S. J. Robben (2004). "The Impact of Market Orientation, Product Advantage, and Launch Proficiency on New Product Performance and Organizational Performance". J PROD INNOV MANAG. Vol. 21. pp. 79-94.

Latiff, Z. A. and F. N. S. Z. Alam (2013). "The Roles of Media in Influencing Women Wearing Hijab: An Analysis". Journal of Image and Graphics. Vol. 1. No. 1, March 2013. pp. 50-54. https://doi.org/10.12720/joig.1.1.50-54

Lee, L. T.-S. (2008). "The effects of team reflexivity and innovativeness on new product development performance". Industrial Management \& Data Systems. Vol. 108 (2008). No. 4. pp. 548 - 569. https://doi. org/10.1108/02635570810868380

Leonidou, L. C., D. Palihawadana and M. Theodosiou (2011). "National Export-Promotion Programs as Drivers of Organizational Resources and Capabilities: Effects on Strategy, Competitive Advantage, and Performance". Journal of International Marketing. 2011, American Marketing Association, Vol. 19, No. 2, 2011, pp. 1-29. https://doi.org/10.1509/jimk.19.2.1

Lewrick, M., M. Omar and J. Robert L. Williams (2011). “Market Orientation and Innovators' Success: an Exploration of the Influence of Customer and Competitor Orientation”. Journal of Technology Management \& Innovation. Volume 6. Issue 3. https://doi.org/10.4067/s0718-27242011000300004 
Lumpkin, G. T. and G. G. Dess (1996). "Clarifying The Entrepreneurial Orientation Construct And Linking It To Performance". Academy of Management Review. Vol. 21. No. 1. pp. 135 - 172. https://doi.org/10.5465/ amr.1996.9602161568

Matanda, M. J. and N. O. Ndubisi (2009). "Market orientation, supplier perceived value and business performance of SMEs in a Sub-Saharan African nation". Journal of Enterprise Information Management. 22. 4. 384-407. https:// doi.org/10.1108/17410390910975013

Matzler, K., E. Schwarz, N. Deutinger and R. Harms (2008). "The Relationship between Transformational Leadership, Product Innovation and Performance in SMEs". Journal of Small Business and Entrepreneurship. Vol. 21. No. 2. pp. 139-152. https://doi.org/10.1080/08276331.2008.10593418

McGrath, R. G. (2013). "The End Competitive Advantage : How Keep Your Strategy Moving as Fast as Your Business". Harvard Business Review. Press Boston, Massachusetts.

Merrilees, B., S. Rundle-Thiele and A. Lye (2011). "Marketing capabilities: Antecedents and implications for B2B SME performance". Industrial Marketing Management. 40 (2011) 368-375. https://doi.org/10.1016/j.indmarman.2010.08.005

Mokhlis, S. (2008). "Consumer Religiosity and the Importance of Store Attributes". The Journal of Human Resource and Adult Learning. Vo. 4. No. 2 (December 2008).

Morgan, N. A. (2012). "Marketing and business performance". J. of the Acad. Mark. Sci. Vo. 40 (2012). pp. 102 - 119.

Morgan, N. A., B. H. Clark and R. Gooner (2002). "Marketing productivity, marketing audits, and systems for marketing performance assessment Integrating multiple perspectives". Journal of Business Research. Vol. 55. pp. 363-375. https://doi.org/10.1016/s0148-2963(00)00162-4

Naidoo, V. (2010). "Firm survival through a crisis: The influence of market orientation, marketing innovation and business strategy". Industrial Marketing Management. Vol. 39 (2010). pp. 1311-1320. https://doi.org/10.1016/j. indmarman.2010.02.005

Nakata, C., S. Im, H. Park and Y.-W. Ha (2006). "Antecedents and consequence of Korean and Japanese new product advantage”. Journal of Business Research. Vol. 59. No. 1. pp. 28-36. https://doi.org/10.1016/j.jbusres.2005.03.008

Narver, J. C. and S. F. Slater (1990). "The Effect of a Market Orientation on Business Profitability”. Journal of Marketing. October 1990. pp. 20 - 35. https://doi.org/10.2307/1251757

Nuraini (2015). "Fesyen Muslim Indonesia". WARTA EKSPOR. Kementrian Perdagangan Republik Indonesia.

Pehrsson, A. (2011). "Firms' customer responsiveness: relationships with competition, market growth, and performance". Journal of Strategy and Management. Vol. 4. Iss 4. pp. 347-336. https://doi.org/10.1108/17554251111181007

Pehrsson, A. (2014). "Firms' customer responsiveness and performance: the moderating roles of dyadic competition and firm's age". Journal of Business \& Industrial Marketing. Vol. 29. Iss 1. pp. 34 - 44. https://doi.org/10.1108/ jbim-01-2011-0004

Prasertsang, S. and P. Ussahawanitchakit (2011). "CORPORATE SOCIAL RESPONSIBILITY STRATEGY, MARKETING PERFORMANCE AND MARKETING SUSTAINABILITY: AN EMPIRICAL INVESTIGATION OF ISO 14000 BUSINESSES IN THAILAND”. INTERNATIONAL JOURNAL OF BUSINESS STRATEGY, Volume 11, Number 3, 2011. Volume 11. Number 3, 2011. pp. 58 - 77.

Ray, J. J. a. D. D. (1972). "Religiocentrism \& Ethnocentrism: Catholic and Protestant in Australian Schools". Sociological Analysis. Vol. 32. No. 3. pp. 170-179. https://doi.org/10.2307/3710000

Rojas-Me'ndez, J. I. and M. Rod (2013). "Chilean wine producer market orientation: comparing MKTOR versus MARKOR". International Journal of Wine Business Research. Vol. 25. No. 1. pp. 27 - 49. https://doi. org/10.1108/17511061311317291

Sandvik, I. L. and K. r. Sandvik (2003). "The impact of market orientation on product innovativeness and business performance". Intern. J. of Research in Marketing. Vol. 20 (2003). pp. 355-376. https://doi.org/10.1016/j.ijresmar.2003.02.002

Shah Alam, S., R. Mohd and B. Hisham (2011). "Is religiosity an important determinant on Muslim consumer behaviour in Malaysia?”. Journal of Islamic Marketing. 2. 1. 83-96. https://doi.org/10.1108/17590831111115268

Shergill, G. S. and R. Nargundkar (2005). "Market Orientation, Marketing Innovation as Performance Drivers". Journal of Global Marketing. 19. 1. 27-47. https://doi.org/10.1300/j042v19n01_03 
Slater, S. F. and J. C. Narver (1995). "Market orientation and the learning organization". Journal of Marketing. Vol. 59. No. 3. pg. 63. https://doi.org/10.2307/1252120

Slater, S. F. and J. C. Narver (2000). "The Positive Effect of a Market Orientation on Business Profitability: A Balanced Replication “. Journal of Business Research. Vol. 48. pp. 69-73. https://doi.org/10.1016/s0148-2963(98)00077-0

Sok, P., A. O'Cass and K. M. Sok (2013). "Achieving superior SME performance : Overarching role of marketing, innovation, and learning capabilities". Australasian Marketing Journal. 21 (2013) 161-167. https://doi.org/10.1016/j.ausmj.2013.04.001

Soliman, H. S. (2011). "Customer Relationship Management and Its Relationship to the Marketing Performance". International Journal of Business and Social Science. Vol. 2. No. 10, June 2011.

Song, L. Z., M. Song and C. A. D. Benedettob (2011). "Resources, supplier investment, product launch advantages, and first product performance". Journal of Operations Management. Vol. 29 (2011). pp. 86-104. https://doi. org/10.1016/j.jom.2010.07.003

Song, M. and J. Noh (2006). "Best new product development and management practices in the Korean high- tech industry". Industrial Marketing Management. Vol. 35 (2006). pp. 262-278. https://doi.org/10.1016/j.indmarman.2005.04.007

Sterkens, C. and F.-V. Anthony (2008). "A Comparative Study of Religiocentrism among Christian, Muslim and Hindu Students in Tamil Nadu, India”. Journal of Empirical Theology. 21. 1. 32-67. https://doi.org/10.1163/092229308x310731

Wang, C. L. and P. K. Ahmed (2007). "Dynamic capabilities: a review and research agenda". International Journal of Management Reviews. Vol.9. pp. 31-51. https://doi.org/10.1111/j.1468-2370.2007.00201.x

Wang, Y. and H. Feng (2012). "Customer relationship management capabilities : Measurement, antecedents and consequences”. Management Decision. Vol. 50. No. 1. pp. 115 - 129. https://doi.org/10.1108/00251741211194903

Wang, Z. and N. Wang (2012). "Knowledge sharing, innovation and firm performance". Expert Systems with Applications. Vol. 39. pp. 8899-8908.

Wei, Y. S., S. Samiee and R. P. Lee (2014). "The influence of organic organizational cultures, market responsiveness, and product strategy on firm performance in an emerging market". J. of the Acad. Mark. Sci. Vol. 42. pp. 49-70. https://doi.org/10.1007/s11747-013-0337-6

Wei, Y. S. and Q. Wang (2011). "Making sense of a market information system for superior performance: The roles of organizational responsiveness and innovation strategy “. Industrial Marketing Management. Vol. 40. pp. 267-277. https://doi.org/10.1016/j.indmarman.2010.06.039

Wong, S. K. S. (2012). "The influences of entrepreneurial orientation on product advantage and new product success". Journal of Chinese Entrepreneurship. Vol. 4. No. 3. pp. 243-262. https://doi.org/10.1108/17561391211262175

Yalcinkaya, G., R. J. Calantone and D. A. Griffith (2007). "An Examination of Exploration and Exploitation Capabilities : Implications for Product Innovation and Market Performance”. Journal of International Marketing. Vol. 15, No. 4, 2007. pp. 63-93. https://doi.org/10.1509/jimk.15.4.63

Zhou, K. Z., J. R. Brown and C. S. Dev (2009). "Market orientation, competitive advantage, and performance: A demand-based perspective". Journal of Business Research. 62. 11. 1063-1070. https://doi.org/10.1016/j.jbusres.2008.10.001 


\section{Apendix}

We are given freedom to be creative in finding new ideas that support marketing effectiveness

We often try new ways that can support the effectiveness of marketing programs

We continuously improve the appearance of products offered to the market

We introduce new models of products to the market almost every month

We have the ability to quickly respond to the changing product design needs

We have the ability to quickly respond to the changing of product motif variations needs

We have the ability to respond quickly to changes in product needs

We have the ability to respond quickly to changing product model requirements

We have the ability to respond to changes in demand appropriately

We always offer products with more aesthetic design than other companies

We always offer products with models that are more fashionable than other companies

We always offer products that are more compliant with religious norms than other companies

The sales results of our company have grown significantly over the past 3 years

The sales volume of our company has increased over the past 3 years

Over the past 3 years our company's sales targets have always been well achieved

The number of our company customers has increased over the last 3 years

Apendix : Measures

Innovativeness (INN), adapted from Lumpkin and Dess (1996)

Kami diberi kebebasan berkreasi dalam menemukan ide-ide baru yang menunjang efektivitas pemasaran

Kami sering mencoba cara-cara baru yang dapat menunjang efektivitas program-program pemasaran

Kami terus menerus memperbaiki penampilan produk yang ditawarkan ke pasar

Hampir setiap bulan kami memperkenalkan produk dengan model baru ke pasar

Customers Responsiveness (CRS), adapted from Daugherty, et al.(1995) and Chavosha, et al. (2011)

Kami memiliki kemampuan merespon perubahan kebutuhan desain produk dengan cepat

Kami memiliki kemampuan merespon perubahan kebutuhan variasi motif produk dengan cepat

Kami memiliki kemampuan merespon perubahan kebutuhan bahan baku produk dengan cepat

Kami memiliki kemampuan merespon perubahan kebutuhan model produk dengan cepat

Kami memiliki kemampuan merespon perubahan permintaan dengan tepat

Religio-centric Fashion Advantage (RFA), new instrumen

Kami selalu menawarkan produk dengan desain lebih estetik dibanding perusahaan lain

Kami selalu menawarkan produk dengan model yang lebih fashionable dibanding perusahaan lain

Kami selalu menawarkan produk yang lebih patuh pada norma-norma religi dibanding perusahaan lain

Kinerja Usaha Kecil (KUK) adaptade from Merrilees et al. (2011) and Healy, et al. (2014)

Hasil penjualan perusahaan kami telah tumbuh secara signifikan selama kurun waktu 3 tahun terakhir

Volume penjualan perusahaan kami mengalami peningkatan selama kurun waktu 3 tahun terakhir

Selama kurun waktu 3 tahun terakhir target-target penjualan perusahaan kami selalu tercapai dengan baik

Jumlah pelanggan perusahaan kami mengalami peningkatan selama kurun waktu 3 tahun terakhir 